\title{
Shear-wave anisotropy beneath the Ryukyu arc
}

\author{
Mamoru Nakamura and Ai Yamamoto \\ Department of Physics and Earth Sciences, Faculty of Science, University of the Ryukyus, Okinawa 903-0213, Japan
}

(Received December 18, 2003; Accepted July 7, 2009; Online published November 30, 2009)

\begin{abstract}
We have investigated regional shear-wave splitting beneath the Ryukyu arc in order to clarify the mantle flow beneath the Ryukyu arc and compare it with the extension of the Okinawa Trough. The splitting of regional shear waves (direct $S$ ) in the central and southern Ryukyu arc regions was analyzed in terms of fast-polarization direction and delay time using data from 11 short-period stations and two broadband seismic stations. The events occurred at depths ranging between 45 and $217 \mathrm{~km}$, and the magnitude of the events ranged from 2.8 to 5.2 . In general, the orientations of fast polarization were found to parallel to the strike of the Ryukyu Trench, with average delay times of $0.25-0.56 \mathrm{~s}$. Specifically, the orientation of fast polarization was parallel to the direction of the extension in the south Ryukyu arc, suggesting that the direction of mantle flow is parallel to the extension in the south Okinawa Trough. However, the orientation of fast polarization was oblique to the direction of extension in the central Ryukyu arc, indicating that the mantle flow beneath the central Ryukyu arc is not parallel to the extension of the central Okinawa Trough. Based on these results, we suggest that the difference between the direction of the mantle flow and that of the lithosphere extension induces extensional strain with a simple shear component, which in turn causes oblique rifting in the central Okinawa Trough.
\end{abstract}

Key words: $S$-waves, wave splitting, seismic anisotropy, Ryukyu arc, Okinawa Trough.

\section{Introduction}

The Okinawa Trough, which is in the rifting stage (Letouzey and Kimura, 1985; Sibuet et al., 1995, 1998), is a good test field for studying the deformation of arcs migrating away from the continent. The deformation in the Okinawa Trough and the Ryukyu arc is evident in the $\mathrm{N}-\mathrm{S}$ extension and southward migration of the Okinawa Trough. The extension in the central and southern Ryukyu arc regions are in the SSE and south directions, respectively, based on global positioning system (GPS) measurements (Nakamura, 2004). In contrast, the extensional axes of the focal mechanism solutions in the central and southern Okinawa Trough are oriented NNW-SSE and N-S, respectively (Fournier et al., 2001; Kubo and Fukuyama, 2003).

Investigation of the mantle flow beneath the Okinawa Trough would shed light on the mechanism of extension of the trough. The observed $S$-wave splitting in the mantle wedge is induced by aligned olivine, and the polarization of fast $S$-waves is oriented in the direction of mantle flow (Zhang and Karato, 1995). Fast polarizations parallel to the trench have been observed in Japan (Okada et al., 1995; Fouch and Fischer, 1996), Kamchatka (Peyton et al., 2001), New Zealand (Marson-Pidgeon et al., 1999; Audoine et al., 2000), and Tonga (Smith et al., 2001). Analysis of $S$-wave splitting is expected to reveal whether the extension of the Okinawa Trough is coupled to the mantle flow beneath the Ryukyu arc and Okinawa Trough.

Copyright (c) The Society of Geomagnetism and Earth, Planetary and Space Sciences (SGEPSS); The Seismological Society of Japan; The Volcanological Society of Japan; The Geodetic Society of Japan; The Japanese Society for Planetary Sciences; TERRAPUB.

\section{Data and Analysis}

The data used in this study were recorded at 11 shortperiod Japan Meteorological Agency (JMA) stations distributed along the Ryukyu Islands and two broadband seismometers at the National Research Institute for Earth Science and Disaster Prevention (NIED) (Fig. 1). Data sampling rates were 100 samples/s for the JMA stations and 80 samples/s for the broadband stations. Events with shearwave incidence angles of less than $35^{\circ}$ and occurring between January 1, 1999 and August 31, 2002 for the JMA stations and January 1, 2001 and August 31, 2003 for the NIED data were analyzed. The events occurred at depths ranging between 45 and $217 \mathrm{~km}$ (Fig. 2), although most events occurred at depths shallower than $100 \mathrm{~km}$. The ray paths were distributed toward the trench side. The magnitude of events ranged from 2.8 to 5.2. A total of 135 and 306 traces were selected for analysis of the central and south Ryukyu arc regions, respectively.

We used a cross-correlation method to detect the splitting parameters (Ando et al., 1983). The horizontal seismograms were first band-pass filtered between 0.5 and $4.0 \mathrm{~Hz}$, and the two horizontal seismograms were then rotated in the horizontal plane at $1^{\circ}$ increments from $0^{\circ}$ to $179^{\circ}$. The seismograms were then cross-correlated in the selected $S$-wave time window, with an increment time-shift of $0.01 \mathrm{~s}$ from 0 to $2 \mathrm{~s}$. When the absolute value of the cross-correlation coefficient reached its maximum, the rotation direction was chosen for the fast-polarization direction, and the time lag was measured as the delay time of the slow shear wave (Fig. 3). Results were accepted only when the maximum cross-correlation coefficient was greater than 0.75 .

The direction of the corrected particle motion was ex- 


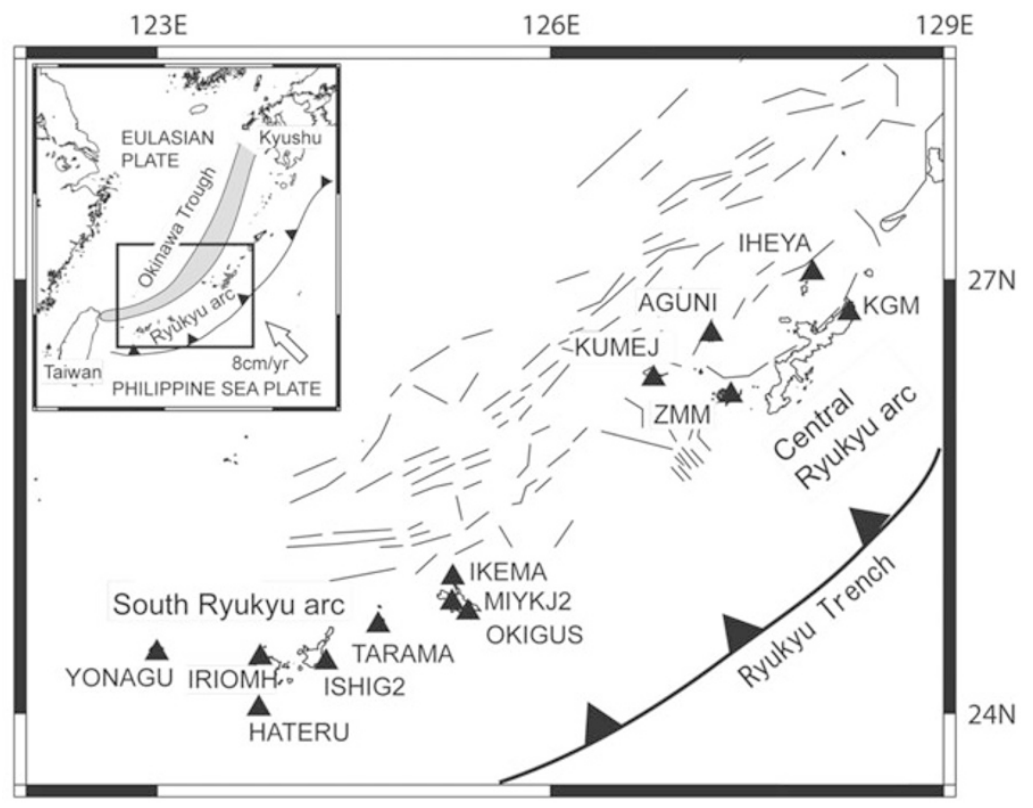

Fig. 1. Tectonic features of the study area. Arrows indicate the velocity of the Philippine Sea plate relative to the Eurasian plate (Seno et al., 1993). Triangles denote seismic stations (as labeled). Solid lines indicate active faults around the Okinawa Trough (Kimura et al., 1999).

pected to be parallel to the polarization radiated from the source. For the events whose Centroid Moment Tensor (CMT) solutions were determined, we compared the corrected particle motion with the computed one. We found that the direction of the corrected particle motion was parallel to the polarization computed using a CMT well solution (Fig. 3). The observed delay times were typically found to be as large as $0.2 \mathrm{~s}$, which cannot be explained by the phase shift at the Moho discontinuity or upper boundary of the subducting slab (Okada et al., 1995). Thus, we concluded that the observed delay time and fast polarization were caused by shear-wave splitting.

\section{Results}

The splitting parameters are presented in Table 1, and the fast-polarization results are shown in Fig. 4.

The earthquakes at depths shallower than $70 \mathrm{~km}$ resulted in fast polarizations that varied among the stations. At stations IHEYA, AGUNI, and KGM, fast polarizations are aligned NE-SW. At stations KUMEJ and ZMM, fast polarizations are aligned NNE-SSW and ESE-WNW, respectively. At stations TARAMA, HATERU, ISHIG2, and YONAGU, fast polarizations are aligned E-W. The fast polarizations at IKEMA, MIYKJ2, and OKIGUS differ for the same events, with OKIGUS exhibiting a bimodal distribution of fast polarizations.

The earthquakes at depths of over $70 \mathrm{~km}$ resulted in fast polarizations parallel to the trench. The fast polarizations are aligned NE-SW at IHEYA, AGUNI, KUMEJ, and $\mathrm{KGM}$, which is parallel to the strike of the trench, oblique to the extensional axis of the focal mechanism solution in the central Okinawa Trough, and perpendicular to the direction of Philippine Sea plate motion relative to the Eurasian plate $\left(\mathrm{N} 55^{\circ} \mathrm{W}\right.$ at $\left.128^{\circ} \mathrm{E}\right)$ (Liu et al., 1995). The fast polarizations are aligned E-W at TARAMA and YONAGU, which is parallel to the strike of the trench, perpendicular to the extensional axis of the focal mechanism solution in the southern Okinawa Trough, and oblique to the direction of Philippine Sea plate motion relative to the Eurasian plate ( $\mathrm{N} 53^{\circ} \mathrm{W}$ at $124^{\circ} \mathrm{E}$ ) (Liu et al., 1995). In contrast, the fast polarizations are aligned N-S at IRIOMH and ISHIG.

\section{Discussion}

The stations in the central Ryukyu arc (IKEMA, MIYKJ2, and OKIGUS) are distributed over an area of only a few tens of kilometers. However, the observed fast polarizations in these stations were found to differ for the same events, suggesting that the observed anisotropy is likely to have been influenced by shallow crustal anisotropic bodies near the stations. However, because few crustal events occur beneath the stations, the contribution of crustal anisotropic bodies at these shallow depths cannot be separated from the observed anisotropy.

For all of these stations where earthquakes have been observed to occur at depths of over $70 \mathrm{~km}$, delay times showed slight increases with earthquake depth (Fig. 5). The mid-points between the hypocenters and stations were distributed at depths of $50-100 \mathrm{~km}$ in the wedge mantle, which is above the subducting slab (Fig. 6). Thus, the observed fast polarizations showed anisotropy at the wedge mantle beneath the forearc.

In general, the observed fast polarizations are oriented mainly parallel to the trench, which is consistent with the results obtained by F-net array in the Ryukyu arc (Long and van der Hilst, 2006). Trench-parallel polarization at the forearc has been observed in northeastern Japan (Okada et al., 1995), New Zealand (Marson-Pidgeon et al., 1999; Audoine et al., 2000), and Tonga (Smith et al., 2001). In these regions, the fast polarizations are oriented parallel to the dip direction of the slab at the backarc, while they are oriented perpendicular to the dip direction at the forearc. The observed fast polarization in the Ryukyu arc, which is 
(a)

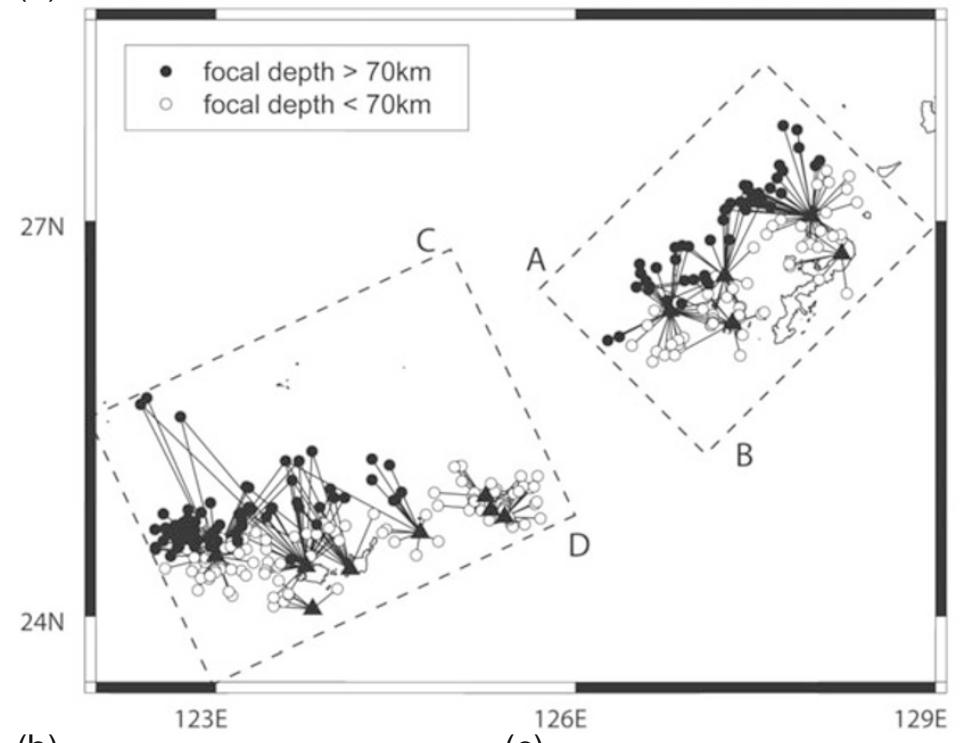

(b)

(C)
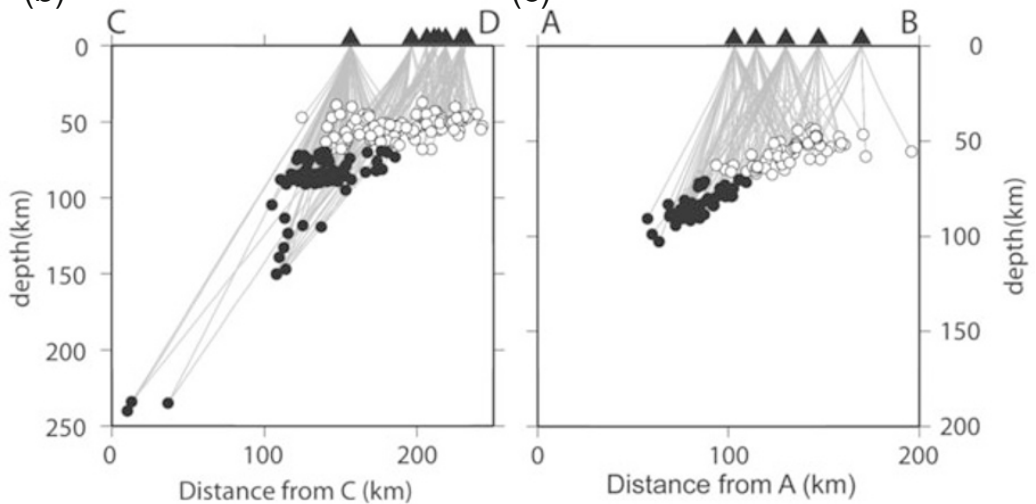

Fig. 2. (a) Network and data set used for analysis of the Ryukyu arc. Earthquakes for which there is a fast-polarization direction are plotted. Rays are traced for earthquake-station pairs that gave a result. $\mathrm{AB}$ and $\mathrm{CD}$ are lines that define the cross-sections presented below. Triangles represent stations. (b), (c) Vertical cross section of rays along line $\mathrm{CD}$ and $\mathrm{AB}$, respectively.
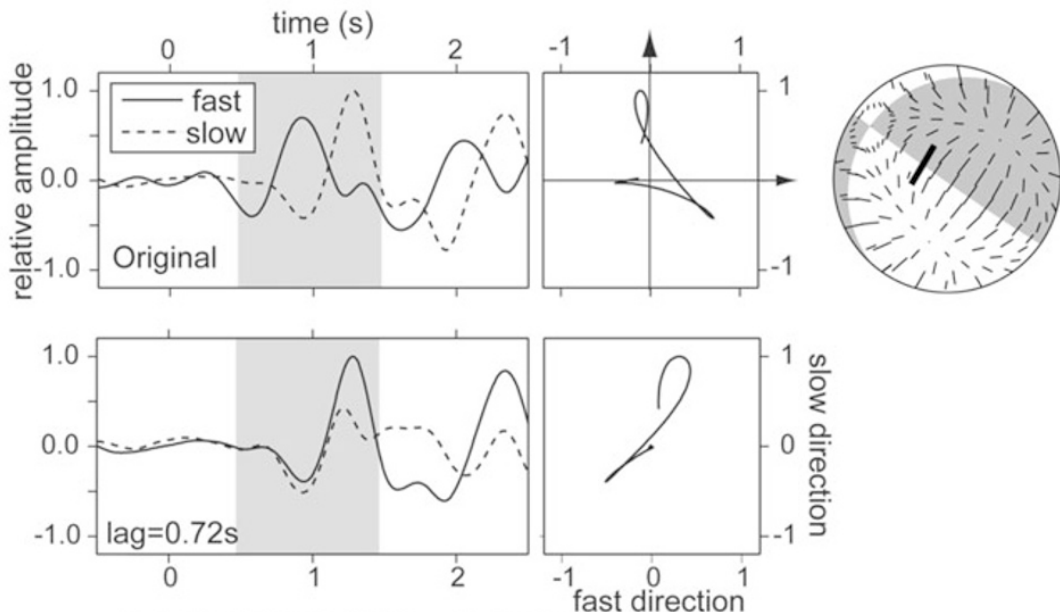

Date: Feb.17 2001 08:13 Depth:88km M4.8

Fast Polarization $=\mathrm{N} 113^{\circ} \mathrm{E}$

Fig. 3. Example of delay-time determination for an earthquake recorded at YONAGU. (Left) The upper diagram is the superposition of fast and slow components before correction for delay time, and the bottom diagram shows fast and slow components for the delay time that give the highest cross-correlation results. The shaded area represents the window used to process the cross section. (Center) The upper diagram is the particle motion for pairs of seismograms, and the bottom shows the particle motion for the corrected components after the splitting effect. (Right) CMT solution was provided by the National Research Institute for Earth Science and Disaster Prevention. Thick and thin lines show the observed and computed $S$-wave particle motion, respectively. The observed particle motion was corrected by removing the splitting effect. 
Table 1. Average fast polarization and delay times at each station.

\begin{tabular}{|c|c|c|c|c|c|c|}
\hline \multirow[t]{2}{*}{ Station } & \multirow[t]{2}{*}{ Lat. $\left({ }^{\circ} \mathrm{N}\right)$} & \multirow[t]{2}{*}{ Long. $\left({ }^{\circ} \mathrm{E}\right)$} & \multicolumn{2}{|c|}{$<70 \mathrm{~km}$} & \multicolumn{2}{|c|}{$>70 \mathrm{~km}$} \\
\hline & & & Fast polarization & Delay times (s) & Fast polarization & Delay times (s) \\
\hline YONAGU & 24.450 & 122.944 & $\mathrm{~N} 94^{\circ} \mathrm{E} \pm 6^{\circ}$ & $0.22 \pm 0.16$ & $\mathrm{~N} 94^{\circ} \mathrm{E} \pm 6^{\circ}$ & $0.29 \pm 0.19$ \\
\hline IRIOMH & 24.386 & 123.749 & $\mathrm{~N} 178^{\circ} \mathrm{E} \pm 11^{\circ}$ & $0.16 \pm 0.12$ & $\mathrm{~N} 5^{\circ} \mathrm{E} \pm 20^{\circ}$ & $0.27 \pm 0.17$ \\
\hline HATERU & 24.057 & 123.805 & $\mathrm{~N} 75^{\circ} \mathrm{E} \pm 14^{\circ}$ & $0.15 \pm 0.11$ & - & - \\
\hline ISHIG2 & 24.364 & 124.143 & - & - & $\mathrm{N} 33^{\circ} \mathrm{E} \pm 20^{\circ}$ & $0.52 \pm 0.24$ \\
\hline TARAMA & 24.641 & 124.702 & $\mathrm{~N} 70^{\circ} \mathrm{E} \pm 14^{\circ}$ & $0.15 \pm 0.11$ & $\mathrm{~N} 88^{\circ} \mathrm{E} \pm 15^{\circ}$ & $0.25 \pm 0.16$ \\
\hline IKEMA & 24.924 & 125.249 & $\mathrm{~N} 85^{\circ} \mathrm{E} \pm 7^{\circ}$ & $0.30 \pm 0.36$ & - & - \\
\hline MIYKJ2 & 24.815 & 125.294 & $\mathrm{~N} 1^{\circ} \mathrm{E} \pm 12^{\circ}$ & $0.30 \pm 0.24$ & - & - \\
\hline OKIGUS & 24.760 & 125.406 & - & - & - & - \\
\hline KUMEJ & 26.326 & 126.786 & $\mathrm{~N} 12^{\circ} \mathrm{E} \pm 15^{\circ}$ & $0.35 \pm 0.26$ & $\mathrm{~N} 5^{\circ} \mathrm{E} \pm 9^{\circ}$ & $0.39 \pm 0.37$ \\
\hline AGUNI & 26.589 & 127.242 & $\mathrm{~N} 70^{\circ} \mathrm{E} \pm 18^{\circ}$ & $0.22 \pm 0.16$ & $\mathrm{~N} 54^{\circ} \mathrm{E} \pm 17^{\circ}$ & $0.30 \pm 0.21$ \\
\hline IHEYA & 27.035 & 127.967 & $\mathrm{~N} 55^{\circ} \mathrm{E} \pm 22^{\circ}$ & $0.23 \pm 0.22$ & $\mathrm{~N} 33^{\circ} \mathrm{E} \pm 14^{\circ}$ & $0.31 \pm 0.24$ \\
\hline ZMM & 26.229 & 127.306 & $\mathrm{~N} 118^{\circ} \mathrm{E} \pm 17^{\circ}$ & $0.49 \pm 0.40$ & - & - \\
\hline KGM & 26.753 & 128.217 & $\mathrm{~N} 44^{\circ} \mathrm{E} \pm 21^{\circ}$ & $0.34 \pm 0.29$ & - & - \\
\hline
\end{tabular}

(a)

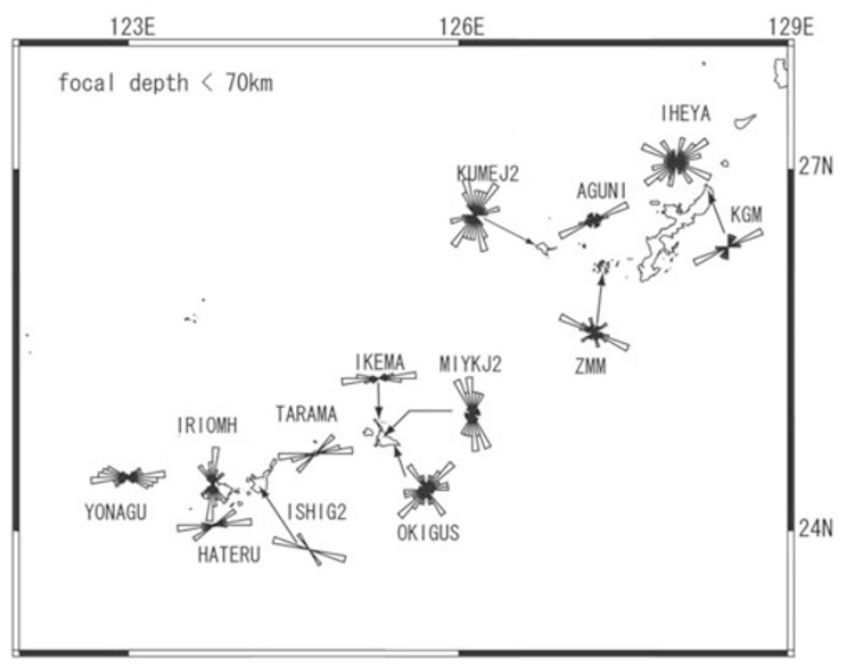

(b)

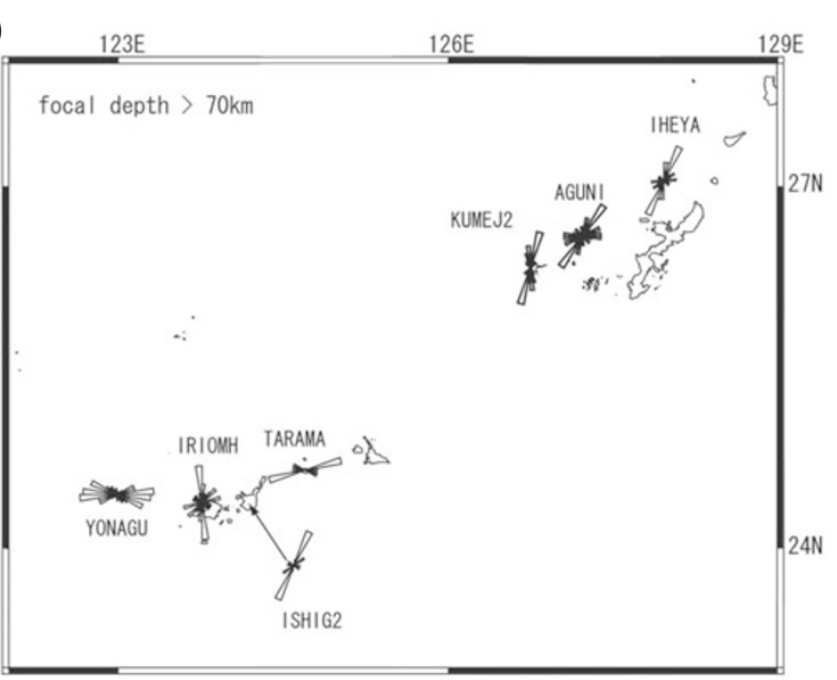

Fig. 4. Rose diagrams of fast-polarization directions at (a) a depth range of less than $70 \mathrm{~km}$, and (b) a depth range of greater than $70 \mathrm{~km}$. The lengths of the rose diagrams are given in proportion to the number of arrivals in $10^{\circ}$ intervals in order to show the main maximum more clearly.

parallel to the trench, is consistent with the results in these regions.

The central and south Ryukyu arc is moving south relative to the Eurasian plate, as measured by GPS (Fig. 6) (Nakamura, 2004). The extensional directions estimated from the focal mechanism solution beneath the central and south Okinawa Trough are NNW-SSE and N-S, respectively (Fig. 6) (Fournier et al., 2001; Kubo and Fukuyama, 2003), suggesting that the mantle flow beneath the south Okinawa Trough trends N-S. However, this is perpendicu- 


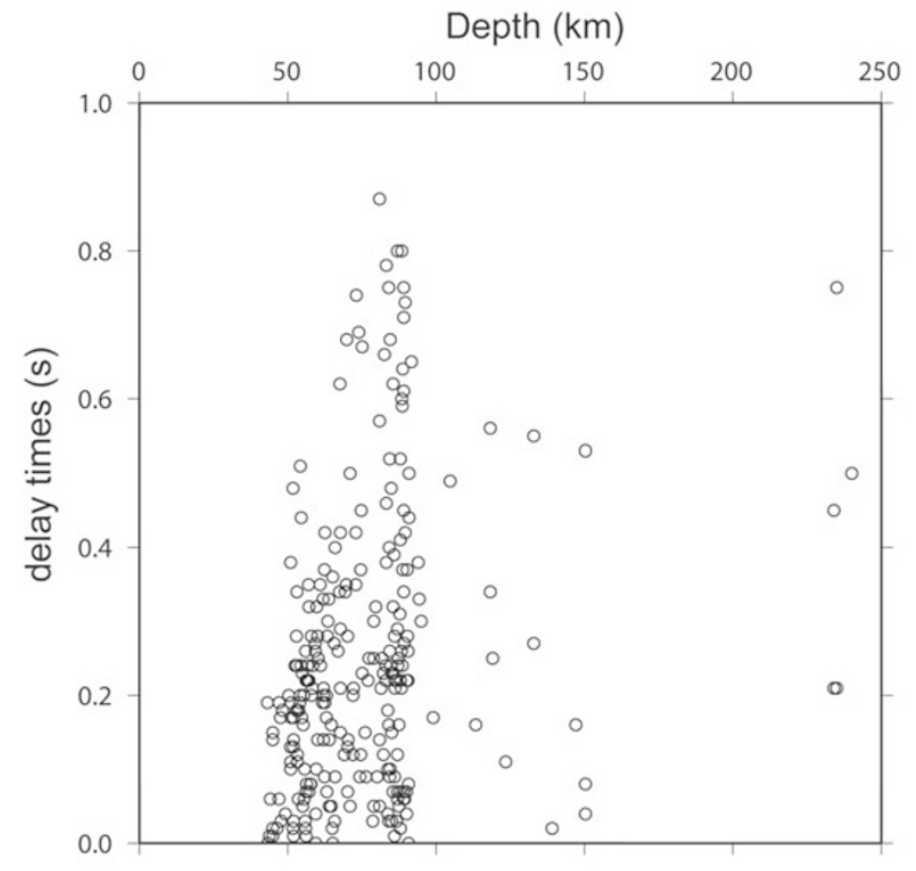

Fig. 5. Relationship between the delay times and the focal depths.

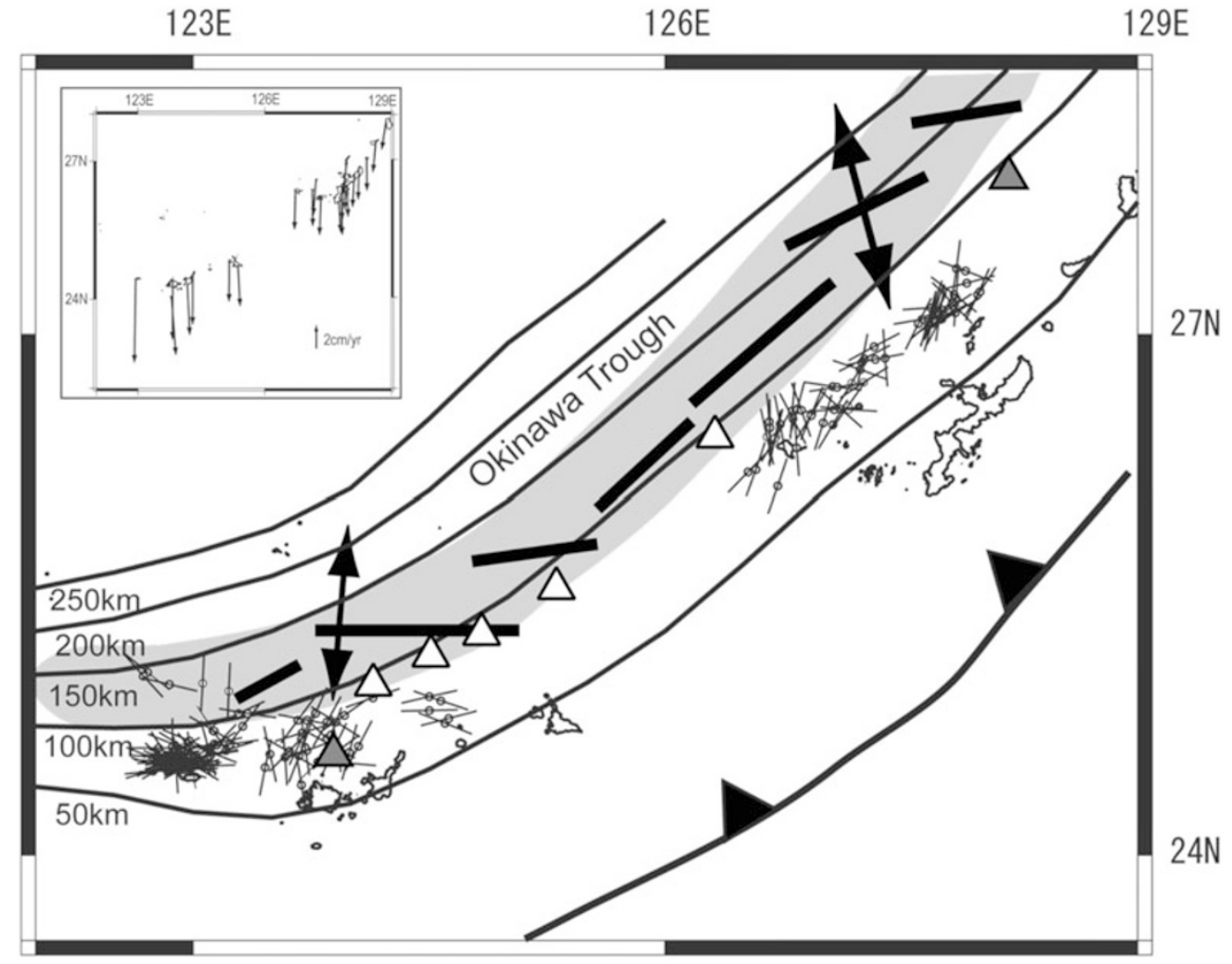

Fig. 6. Fast-polarization directions for the $S$ phase plotted by bar azimuth from the north at the station sites. Contours for the Wadati-Benioff zone are adapted from Nakamura and Kaneshiro (2000). Thick arrows indicate the extensional axes of focal mechanism solutions for shallow earthquakes in the Okinawa Trough (Fournier et al., 2001; Kubo and Fukuyama, 2003). (Inset) Horizontal velocity of GPS stations relative to South China (Nakamura, 2004).

lar to the fast polarization oriented E-W in the south Ryukyu arc. Such a condition is consistent with the model in which the direction of fast polarization is perpendicular to the flow in water-rich and high-strain-rate conditions (Jung and
Karato, 2001).

Fast polarization parallel to the trench was found to be oblique to the extensional direction of the central Okinawa Trough in the central Ryukyu arc, suggesting that the 
mantle flow beneath the central Ryukyu arc would move obliquely toward the extension of the central Okinawa Trough. This oblique crustal movement against the mantle flow would induce shear strain in the pure extension in the central Okinawa Trough. The formation of the central Okinawa Trough involves a combination of extension and simple shear strain (Fournier et al., 2001). Strikeslip and normal faulting events are dominant in the central Okinawa Trough, while normal-fault type events are dominant in the south Okinawa Trough (Fournier et al., 2001; Kubo and Fukuyama, 2003). A shear component in the central Okinawa Trough would be induced by the oblique deformation between mantle flow and overlying lithospheric extension.

\section{Conclusions}

Analysis of $S$-wave splitting revealed upper-mantle anisotropy beneath the central and southern regions of the Ryukyu arc. The direction of fast $S$-waves in the central and southern Ryukyu arc regions is parallel to the strike of the Ryukyu Trench, demonstrating that the direction of mantle flow is parallel to the extension in the south Okinawa Trough. However, trench-parallel polarization is oblique to the extension of the central Okinawa Trough in the central Ryukyu arc, suggesting that the mantle flow beneath the central Ryukyu arc would not be coherent with the extension of the central Okinawa Trough. The difference between the direction of the mantle flow and that of lithosphere extension would induce extension strain with simple shear strain in the central Okinawa Trough.

Acknowledgments. We are grateful to the staff of the Japan Meteorological Agency and the National Research Institute for Earth Science and Disaster Prevention for providing the high-quality waveform data used in this research. S. Tsukada is gratefully thanked for his helpful advice. We are also grateful to anonymous reviewers for their helpful comments and advice.

\section{References}

Ando, M., Y. Ishikawa, and F. Yamazaki, Shear-wave polarization anisotropy in the upper mantle beneath Honshu, Japan, J. Geophys. Res., 88, 5850-5864, 1983.

Audoine, E., M. K. Savage, and K. Gledhill, Seismic anisotropy from local earthquakes in the transition region from a subduction to a strike-slip plate boundary, New Zealand, J. Geophys. Res., 105, 8013-8033, 2000.

Fouch, M. J. and K. M. Fischer, Mantle anisotropy beneath Northwest Pacific subduction zones, J. Geophys. Res., 101, 15987-16002, 1996.
Fournier, M., O. Fabbri, J. Angelier, and J.-P. Cadet, Regional seismicity and on-land deformation in the Ryukyu arc: implications for the kinematics of opening of the Okinawa Trough, J. Geophys. Res., 106, 13751-13768, 2001.

Jung, H. and S. Karato, Water induced fabric transitions in olivine, Science, 293, 1460-1463, 2001.

Kimura, M., Y. Wang, and H. Yagi, Submarine geo-structure and tectonics in the Ryukyu arc, Chishitu News, 543, 24-38, 1999 (in Japanese).

Kubo, A. and E. Fukuyama, Stress field along the Ryukyu Arc and the Okinawa Trough inferred from moment tensors of shallow earthquakes, Earth Planet. Sci. Lett., 210, 305-316, 2003.

Letouzey, J. and M. Kimura, Okinawa Trough genesis: Structure and evolution of a back-arc basin developed in a continent, Mar. Pet. Geol., 2, 111-130, 1985.

Liu, X., K. C. McNally, and Z.-K. Shen, Evidence for a role of the downgoing slab in earthquake slip partitioning at oblique subduction zones, J. Geophys. Res., 100, 15351-15372, 1995.

Long, M. D. and R. D. van der Hilst, Shear wave splitting from local events beneath the Ryukyu arc: Trench-parallel anisotropy in the mantle wedge, Phys. Earth Planet. Inter., 155, 300-312, 2006.

Marson-Pidgeon, K., M. K. Savage, K. Gledhill, and G. Stuart, Seismic anisotropy beneath the lower half of the North Island, New Zealand, $J$. Geophys. Res., 104, 20277-20286, 1999.

Nakamura, M., Crustal deformation in the central and southern Ryukyu Arc estimated from GPS data, Earth Planet. Sci. Lett., 217, 389-398, 2004.

Nakamura, M. and S. Kaneshiro, Determination of subducted Philippine Sea plate in the Nansei islands deduced from hypocenter data, Bull. Sci., Univ. Ryukyus, 70, 73-82, 2000.

Okada, T., T. Matsuzawa, and A. Hasegawa, Shear-wave polarization anisotropy beneath the north-eastern part of Honshu, Japan, Geophys. J. Int., 123, 781-797, 1995.

Peyton, V., V. Levin, J. Park, M. Brandon, J. Lees, E. Gordeev, and A. Ozerov, Mantle flow at a slab edge: seismic anisotropy in the Kamchatka region, Geophys. Res. Lett., 28, 379-382, 2001.

Seno, T., S. Stein, and A. E. Gripp, A model for the motion of the Phillipine Sea plate consistent with NUVEL-1 and geological data, J. Geophys. Res., 98, 17941-17948, 1993.

Sibuet, J.-C., S.-K. Hsu, C.-T. Shyu, and C.-S. Liu, Structural and kinematic evolution of the Okinawa trough backarc basin, in Backarc Basins: Tectonics and Magmatism, edited by B. Taylor, pp. 343-378, Plenum, New York, 1995.

Sibuet, J.-C., B. Deffontaines, S.-K. Hsu, N. Thareau, J.-P. Le Formal, C.$\mathrm{S}$. Liu, and ACT party, Okinawa trough backarc basin: Early tectonic magmatic evolution, J. Geophys. Res., 103, 30245-30267, 1998.

Smith, G. P., D. A. Wiens, K. M. Fischer, L. M. Dorman, S. C. Webb, and J. A. Hildebrand, A complex pattern of mantle flow in the Lau backarc, Science, 292, 713-716, 2001.

Zhang, S. and S. Karato, Lattice preferred orientation of olivine aggregates deformed in simple shear, Nature, 375, 774-777, 1995.

M. Nakamura (e-mail: mnaka@sci.u-ryukyu.ac.jp) and A. Yamamoto 